\title{
The Image of Prime Minister Colijn: Public Visualisation of Political Leadership in the $1930 \mathrm{~s}$
}

\author{
Marij Leenders and Joris Gijsenbergh
}

\section{Introduction*}

In the 1930s, the parliamentary system in the Netherlands was under fire, as it was in most European democracies. Parliament, the political parties, and professional politicians were not held in very high regard. However, the critics of the parliamentary system did not actually distance themselves from the idea of political representation. On the contrary, they strove to achieve improvement of the system of representation. These critics were all searching for various, sometimes contradictory solutions to "the crisis of parliamentarism." ${ }^{1}$ Some wished to restore the reputation of parliament in all its old glory. Others sought salvation in strong leaders, convinced that democracy could not continue without authority. They were convinced that these leaders should function as a symbol for the electorate. The debate about representation during the interwar period did not therefore only revolve around the position of parliamentary representation. The relationship between leaders and "the people" was also a recurring theme. The lamentation about parliamentarianism was based on various ideals of political representation and democratic leadership. ${ }^{2}$

This contribution will show the manifold ways in which parliamentary photographers and political artists portrayed Dutch political leaders in the 1930s. Prime Minister Hendrik Colijn, the most prominent statesman of the time, was especially frequently portrayed. The images of Colijn and his colleagues in the parliamentary arena are very relevant to a clear insight into the interwar history of representation. Photographers and caricaturists played an important role in the image-forming of these politicians. Their images drew a realistic view of the statesmen (mimetic representation) but also framed a particular type of politician (aesthetic representation). ${ }^{3}$ The photographers and artists literally formed the image held by the greater public, of politicians and politics.

\footnotetext{
* This chapter is mainly derived from Leenders (2014) and Gijsenbergh (2014).

1 "De crisis van het parlementarisme en de democratie," Het Vaderland, 7 Jan. 1926.

2 Gijsenbergh (2015) 117.

3 Ankersmit (1987) 363 .
} 
Their photos and political caricatures gave a positive or negative impression of Dutch leaders. Analysis of this visual source material clearly shows the various ideals of political representation as it was presented to the public.

Some of the photographers and caricaturists of the 1930s longed back to the nineteenth century, a time when the political arena was populated by respectable and aloof gentlemen. ${ }^{4}$ Compared to France and Germany, democratic participation in The Netherlands started relatively late. Holland resembled Great Britain in that respect. Although Thorbecke's constitutional revision of 1848 already sowed the seeds for a parliamentary form of government, the Dutch parliament remained a closed, aristocratic kind of institute, in which but a very small part of the population felt involved. The "representatives" were free and unfettered to practice their mandate, at a huge distance from the voters. The need to actually represent or express the will of the people was not high on the agenda in The House. After all, Members of Parliament (MPs) were notables, distanced from society, and considered their main task to be to promote general well-being to the best of their ability. ${ }^{5}$

At the end of the nineteenth century, this aloof method of politics made way for the kind that aimed at mobilisation and communication. Political artists such as Pieter de Josselin de Jong (1861-1906) portrayed late-nineteenth century politicians and parliament, but it was specifically several politicians themselves who managed to bridge the gap between politicians and citizens. The leaders of the new political parties in particular, such as the anti-revolutionary leader Abraham Kuyper, and the leader of the Social Democrats Pieter Jelles Troelstra, profiled themselves as spokesmen for their rank and file. ${ }^{6}$ They achieved this not only in the House of Commons, but also in the partisan media and - as far as the Social Democrats were concerned - during mass demonstrations. To these demagogues, politics was not just a matter of business for the pompous gentlemen of The Hague to be concerned with, but something for everyone. They associated politics no longer with business-like, rational discussion, but - as historian Henk te Velde has convincingly demonstrated - with an emotional way of representing various groups of the population. ${ }^{7}$

After 1917, political representation once again changed character, following upon the introduction of the general right to vote (1917/1919) and the system of proportional representation (1917). On the one hand, this new step bridged the

\footnotetext{
4 Aerts (2009) 19 .

5 Aerts (2014) 150-51.

6 Te Velde (2001) 23 .

7 Te Velde (2000) 155-58; Te Velde (2002).
} 
gap between politicians and citizens. More and more politicians now understood the necessity of seeking contact with their voters. Prior to 1917, parliament consisted of district members that often enough rather cherished their distance to local voters. The introduction of proportional representation ensured that MPs now reflected the political ideological divisions of the whole of the Dutch population as accurately as possible. ${ }^{8}$ The introduction of the general right to vote also led to more voters being able to influence political decision-making. On the other hand, political leaders retained the need to keep their distance from "the general public." Now that the electorate was filled with the unskilled and the uneducated, the parties took it upon themselves to channel popular participation. ${ }^{9}$

In the 1930s, and against this background, public debate on representation burst loose. Some party leaders wanted to restore their aloof nineteenth-century type of relationships towards citizens. Other politicians considered such a return to be impossible, but did still want to lead their rank and file. To achieve this, they needed the confidence of the citizens. In the interwar period, the charisma of those in power was then of great importance, just as it had been for centuries already, from ancient times right up to the nineteenth century. Parliamentary photographers and caricaturists played a huge role in this because they helped to shape the image of various politicians. Their representation of Colijn and other leaders is central to this contribution. Editorial staff of magazines publishing the photographs and cartoons have also been considered in the analysis, because they were important intermediaries in the process of representation of leadership, too. Editors were responsible for selecting the images, helped make up the captions, and decided on how the images were printed.

This chapter distances itself from previous literature that emphasises how parliament was criticised from all sides during the $1930{ }^{10}{ }^{10}$ Instead, this contribution will expand upon four recent tendencies within historiography. Following upon recent international historiography, we lay the emphasis here upon the diversity within the broad spectrum of interwar lament about parliamentary democracy. ${ }^{11}$ Secondly, this article follows the literature on the Dutch shift in the formation of representative politics. Henk te Velde researched "the rise of political parties at the end of the nineteenth century" and how they served as catalyst in the process. Jasper Loots demonstrated how the debate on

\footnotetext{
$8 \quad$ Te Velde (2001) 23; Loots (2004) 21-23, 142, 207-210.

$9 \quad$ Gijsenbergh (2017) 140.

10 Berg-Schlosser (2000).

11 Gerard (2005) 504; Gijsenbergh (2015) 117.
} 
representational reform only really took off around 1917, with the introduction of proportional representation. ${ }^{12}$ This chapter shows how the various opinions on representation remained subject to change throughout the 1930s. The emphasis here lies on perceptions on the relationship between representation and authority because that was an important theme among publicists and politicians. This focus hooks up to a third historiographic tendency. Historians such as Moritz Föllmer and Joris Gijsenbergh have shown how the call to leadership in the 1930s was certainly not always directed at the abolishment of democracy. On the contrary, both in and outside The Netherlands, there were many advocates for firm authority who were in fact rooting for improvements of democracy. ${ }^{13}$

The analysis of visual source material forms the fourth way in which this contribution builds upon historiography. Lately, there are more and more historians analysing photographs and political cartoons, but they place these sources insufficiently in context. There appears to be only superficial interest exhibited in the historical connections, leaving photographs incorrectly dated and captions on the photos inaccurately reproduced. Especially where it involves photos by Erich Salomon, who is central to this article. Furthermore, previous authors have seldom made a distinction between the photographs that were published in the press of the time, and photos that remained in the archives. Only published photos can be utilised as a source of visual discourse during the interwar period because only these played any role in the public debate. $^{14}$

One specific category of depiction is the caricature. These often only function in historical research as illustration. Even when they are central to the discussion, the attention often goes to one particular artist's work, the political subject of satire, or the history of a satirical periodical. ${ }^{15}$ Caricatures, however, offer excellent insight as to how the functioning of politicians and the political system itself were sternly judged. Research into visual parliamentary culture is rare. Therefore, this contribution focuses on the visual representation of politicians and parliament in the interwar period. The images will be placed in historical context in order to discover how the photographer, the caricaturist, or the editor(s) wanted the image(s) to be "read."

The visual staging of Colijn's political leadership brings two different repertoires of representation to the fore - both of which garnered praise and

\footnotetext{
12 Te Velde (2001); Loots (2004).

13 Föllmer (2015) 178; Gijsenbergh (2017) 140.

14 Rose (2001) 69-99; Brandt (2013) 354; Burke (2001) 9-13; Beunders (2010) 121, 133-35.

15 Walter (2006); Mulder (1978); Mulder (1985); Van Weringh (1975); Van Weringh (1976); Van Weringh (1977).
} 
derision in the 1930s. Advocates and opponents of these two ideal visions of representation collided regularly. The first section treats images portraying the PM as a "deliberative democrat," who, just as his predecessors in the nineteenth century, exchanged thoughts with other members of The House in a dignified, aloof manner. Photos by the famous Jewish photojournalist Erich Salomon, who fled to Holland after Hitler's rise to power, more than anything outlined a positive view of the deliberative House of Commons and Senate. Salomon praised his host country, where parliamentary manners and morals still existed. This positive vision of parliamentary democracy was not actually common in the Netherlands of the 1930s. The "Chat Club" was under fire from various quarters, such as the Nationaal-Socialistische Beweging 'National Socialist Movement' (NSB), which wanted to abolish democracy and various conservative groups which desired democratic reform. Caricatures in Volk en Vaderland and De Haagsche Post painted deliberative leaders as weak and inefficient.

The second section analyses specific images of Colijn as "disciplined democrat." These portray the PM as a strong, decisive leader, oozing authority. He serves the MPs imperturbably with adequate response and was literally shown to have "the ship's wheel" in his hands. There are several photos by Salomon accompanied by captions, in the independent/liberal weekly journal Het Leven, Geillustreerd - which suggested that Dutch democracy indeed benefited from just such a leader. This message was also conveyed in drawings in De Haagsche Post and De Telegraaf. Caricaturists did not always ridicule politicians: in these images we certainly see a positive depiction of Colijn. But not everyone welcomed a strong leader. According to the caricaturists of the progressive De Groene Amsterdammer and the Social Democratic De Notekraker, strong leadership could turn into authoritarian or even undemocratic leadership.

This chapter therefore touches on the concept of representation in two ways. Firstly, photographs and caricatures created their own representation of reality, by effectively framing political figures. Secondly, analysis of these visual sources brings ideal conceptions of political leadership to the fore. Politicians were portrayed as deliberative leaders or as decisive representatives of the nation. This offers some insight into the kaleidoscope of interwar opinions on authority within parliamentary democracy.

\section{Colijn Portrayed as a Deliberative Democrat}

The Conservative, orthodox-Protestant PM Hendrikus Colijn was portrayed many times from 1936 in Salomon's photographs. This photojournalist was the 


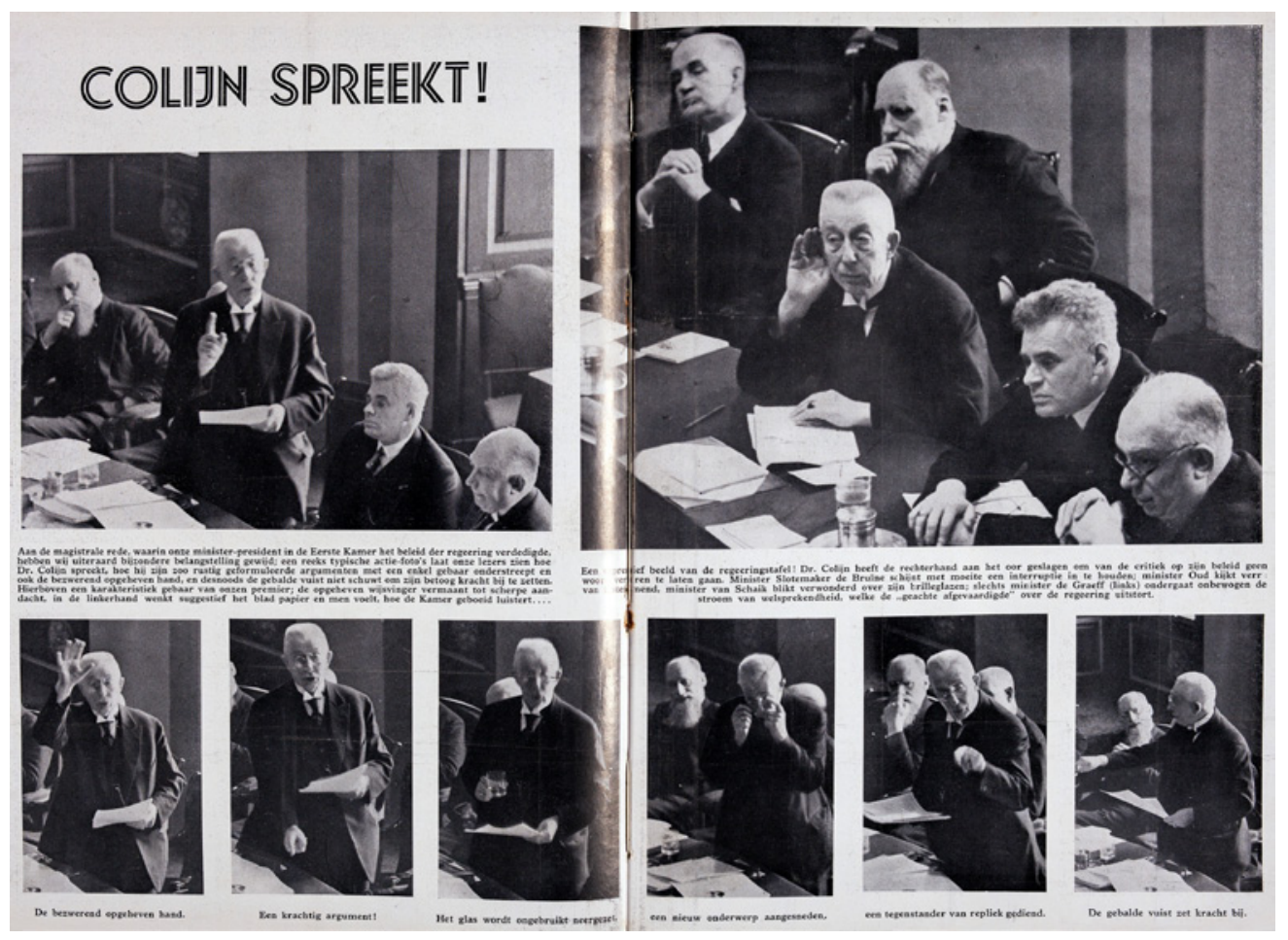

FIGURE 7.1 'Colijn speaks!' in Het Leven, February 22, 1936. PHOTOS: ERICH SALOMON.

first to be given access to parliament (in 1936) in order to photograph MPs and the government in debate. He probably used his good relationship with Colijn to gain this position. He knew Colijn even before coming to Holland and Colijn was one of the first politicians in the Netherlands conscious of the influence of mass-media. ${ }^{16} \mathrm{He}$ was given an inordinate amount of press attention in the 1930s. Many a speech by Colijn was heard on the radio in Dutch households in the 1930s. Colijn also consciously employed (photo) journalists to build up his public persona. Erich Salomon was one of the first photographers to concern himself with Colijn. The selected photographs show Colijn as a deliberative leader, not afraid of and never avoiding debate in parliament.

The first example here was staged by the photographer to portray Colijn as an impassioned and superior statesman in a so-called "Parliamentary Film" with repetitive and explicit captions that emphasise the PM's stance when in debate with The House: "Colijn speaks, Colijn listens, Colijn directs" (see Figure 7.1). This picture shows us a rational and business-like statesman. On a

16 Langeveld (2002). 
double-paged spread, the ministers are depicted behind the cabinet table; Colijn is the dominant figure in the middle during his speech. These photographs were taken from the public grandstand with light falling in from the window. ${ }^{17}$ The deliberative aspect is shown in all its facets in the second example, showing how senator M.M. Mendels (Sociaal-Democratische Arbeiderspartij, SDAP) attacks Colijn's cabinet III. Cabinets III, IV, and V (1935-1939) did not possess a parliamentary majority. The opposition used this to express sharp critique of the government. During Colijn III (1935-1937), consisting of central/right parties, Mendels did not hold back in bringing the actual legitimacy of the cabinet into doubt. According to the Social Democratic senator, the PM had insufficiently researched whether the "States General of The Netherlands" had indeed approved this cabinet. In other words, did this cabinet in fact even have the support of parliament? ${ }^{18}$ Salomon made a series of photographs of this debate on 6 or 7 February 1936 that firmly place Mendel's critical speech and Colijn's rejoinder, centre stage (see Figure 7.2). In the very same issue of Het Leven that portrays the debate in The House, we see senator Mendels (also a lawyer and journalist for the Social Democratic daily Het Vrije Volk) vehemently gesticulating on several occasions. Het Leven captions this as follows:

One of the best speakers in parliament is indubitably Mr. Mendels, who frequently peppers his sharp criticisms with humour, and is always given great attention by The House. See the series of 'film' above to follow how he attacks the government [Colijn cabinet III] - surrounded by Dr. Polak, Count de Marchant et d'Ansembourg, Mr. van Vessem and Suze Groeneweg - with fierce gestures and with his hand on his heart to show his conviction. ${ }^{19}$

The fiercest attack on the unparliamentarian character of the new Colijn cabinet $\mathrm{v}$ came from the Catholic opposition. L.N. Deckers, party chairman of the Roomsch-Katholieke Staatspartij (RKSP), criticised Colijn that during the formation of his fifth cabinet, inaugurated on 25 July 1939, he had in no way

17 These photos have also been published in the British Telegraph and in the Daily Telegraph on 29 July 1939 .

18 Related to this issue was the distinction between parliamentary and extra-parliamentary cabinets. Colijn interpreted that in his own way: "Purely parliamentary cabinets in the traditional sense of the word are very rare in the Netherlands, because very seldom did a homogeneous political group in Parliament possess the majority, which means that very seldom a cabinet could be formed of people, who completely politically agreed with that group." Handelingen van de Eerste Kamer der Staten-Generaal (HEK) 1935-1936, 267-68.

Het Leven, 29 Feb. 1936. 

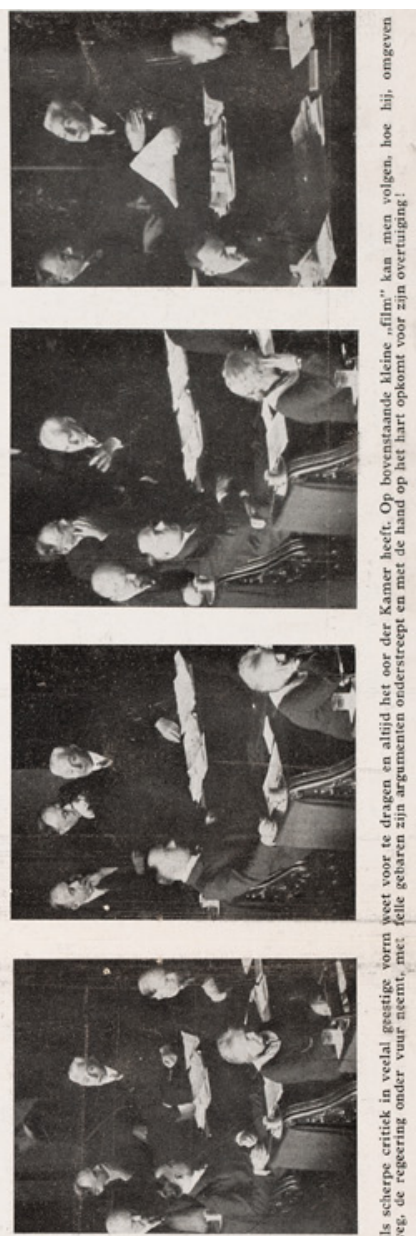

ڤึ
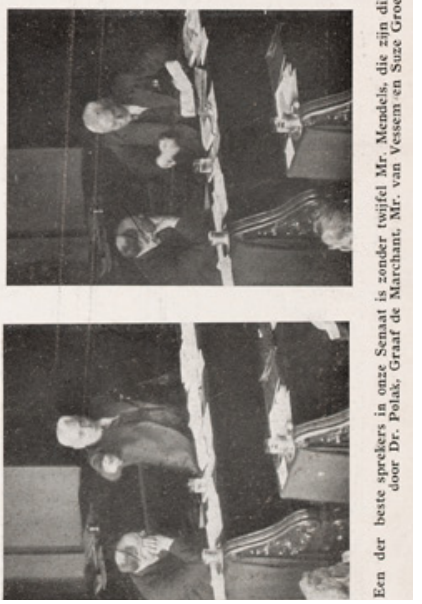


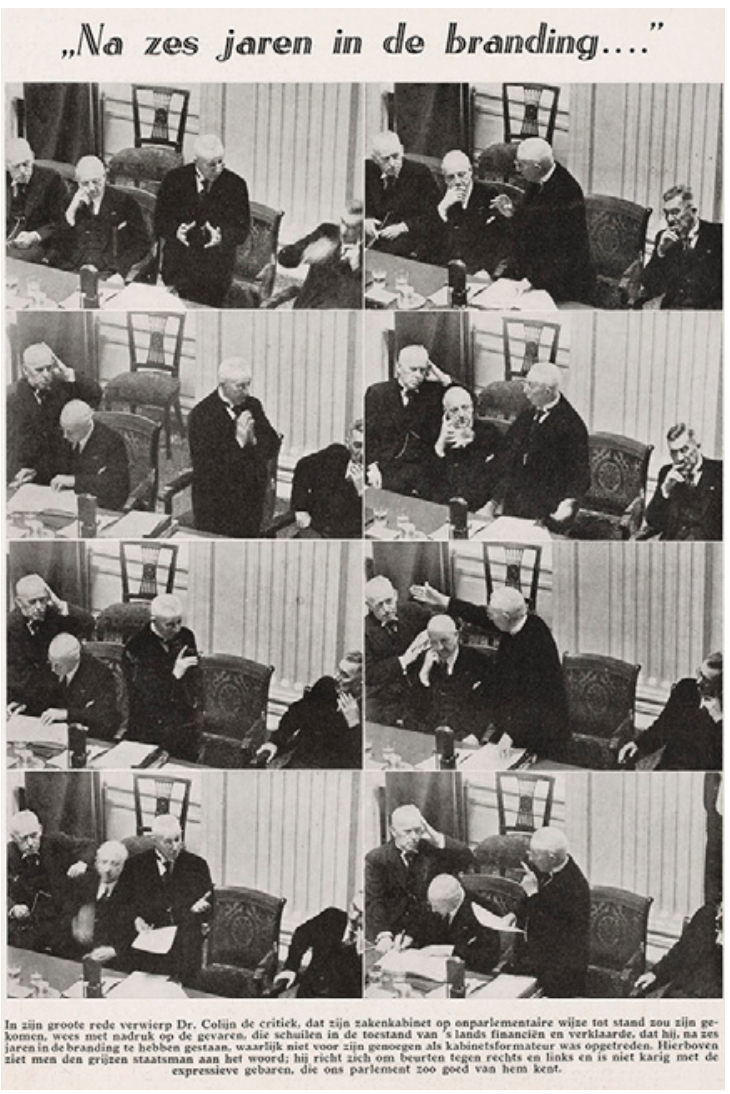

FIGURE 7.3

'After 6 years on the breakers...' in Het Leven, August 8, 1939. PHOTOS: ERICH SALOMON.

accounted for the wishes of parliament. ${ }^{20}$ Deckers officially proposed for the inauguration of Colijn cabinet $\mathrm{v}$ to be denounced.

Colijn defended himself most audaciously, as can be seen in example 3 , but it was to no avail. Decker's proposal was supported by a majority in The House and on 29 July 1939, the cabinet was under resignation. ${ }^{21}$ Salomon recorded Colijn's speech in a series of eight "filmic" images. Het Leven published the photos under the title "After 6 years on the breakers...," a variation on the theme of Colijn's speech to The House where he referred to "standing in the storm for 6 years" (see Figure $7 \cdot 3$ ). ${ }^{22}$ The accompanying editorial reads:

20 Moreover, Deckers argued that the resignation of the previous cabinet was unnecessary and undesirable, due to the economic and political crisis. Handelingen van de Tweede Kamer der Staten-Generaal (HTK) 1938-1939, 2228. HTK 1938-1939, 2225. Ibid. 
Colijn Cabinet no. 5 lasts only two days! Our colleague Dr. Erich Salomon took a series of charming photographs of the session wherein the formateur defends his decisions against critique from both left and right. Above: 'Dr. Colijn listening to Dr. Deckers's speech.'

Deckers is by the way not in the picture. The text continues about Colijn and "his big speech," about how "while the distinguished statesman speaks, he takes turns to face those on the right and then those on the left and does not hold back on the expressive gestures for which parliament knows him so well."

The photo reportage with a series of joined up fragments (snapshots) shows all aspects of a speech in progress, and the supporting body-language clearly aims at both convincing and moving the MPs. Due to the wording of the caption, not just the PM, but the ministers, too, were clearly being documented on their last day in function.

This method of photographing the same person in a series of photographs with short pauses between (see Figures 7.1, 7.2, and 7.3) gives an almost filmlike effect. Het Leven comments on the results of Salomon's method, via captions. Gestures and expressions on Ministers, MPs, speakers, and listeners are actually give attention in his work, making it possible to accurately interpret their state of mind: "Colijn is obviously amused," "minister De Graeff (left) with his thumbs diplomatically pressed one against the other," and "Minister Oud who 'adds a smirk." The editorial staff described the PM as the conductor of the orchestra. Het Leven agreed with Salomon who had previously mentioned the importance of gestures during a speech. ${ }^{23}$ Editors saw the photograph as an accurate depiction of reality (as was then usual to think so) and seemed unconscious of the influence a photograph could have on what was actually happening. Visual staging of Colijn as a rational, business-like, but above all charismatic PM seemed to connect neatly with existing portraiture. In any case, no critical commentary ensued.

Het Leven's intention of reproducing statesman Colijn's work as realistic could also be seen in the photos chosen of cabinet meetings. "Our readership can now form a clear picture of the cabinet wherein 'the country's most important decisions are taken!," as per their editorial. ${ }^{24}$ Pictures of the tumultuous debate of 29 and 30 September 1936 showing Colijn's cabinet departing from "the gold standard" under pressure from parliament also make an attempt at clearly visualising political decision making. The captions emphasise Colijn's

23 Bottema (1936) preface, 108-11.

24 Het Leven, 7 March 1936. 
huge difficulties in agreeing to this economic reform ("only if absolutely necessary"). ${ }^{25}$

With the publication of Salomon's parliamentary photographs, Het Leven took a political stand - deliberately or otherwise. The editors "framed" the photos with their captions in such a way as to present parliamentary democracy positively, in a time that this form of government was being widely criticised. The captions of Salomon's photos suited the critics who actually believed in parliamentary democracy but who also proposed renewal and improvement to the system. ${ }^{26}$ Het Leven worked together with Salomon to reveal how representation must take place via deliberation, with appeals for agreement among the majority of representatives. According to the editors and the photographer, parliamentary debate was not inefficient but indeed a noble component of the game of politics.

Salomon's style of parliamentary photography was closely followed by a few disciples in the interwar period. The work of photographic journalists like Wiel van der Randen and Henk Smits existed mostly of official, posed, political pictures at the start of the 1930s, and yet, photos taken after 1937 are barely distinguishable from Salomon's. There's an interesting depiction of Colijn as "deliberative leader" taken by Wiel van de Randen. In this, he portrays the PM while Colijn holds a relaxed "friendly chat" with the leader of the Communist Party among the parliamentary benches (see Figure 7.4). This portrait placed Colijn somewhere the PM probably could not have foreseen. After all, Colijn derived his authority and popularity, for a not unimportant part, from his image as a warrior against political extremism. This rather proves that Colijn quite clearly did not have his image forming entirely in hand. He was dependent on the photographer, or political caricaturist. Salomon's thematic of a positive image of deliberative leadership was continued here by other photographers. With the use of composition and the choice of just the right psychological instant, Salomon portrayed a determined, engaged leader.

However, this interpretation was not shared by all. Some political caricaturists considered deliberative leadership to be a sign of weakness because politics would become stuck in the quagmire of endless debate. Prime Ministers - Colijn leading the way - could always depend on criticism from the satirical press, specifically because they spent too much time in debate. Deliberative leadership was staged to look from mildly ridiculous to condescending, to reprehensible, in political cartoons. The artists working for the conservative/liberal oriented weekly publication De Haagsche Post (with a circulation of

25 HTK 1936-1937, 31- 6o; Het Leven, 3 Oct. 1936.

26 Kennedy (2004) 13; Gijsenbergh (2015) 133-35. 


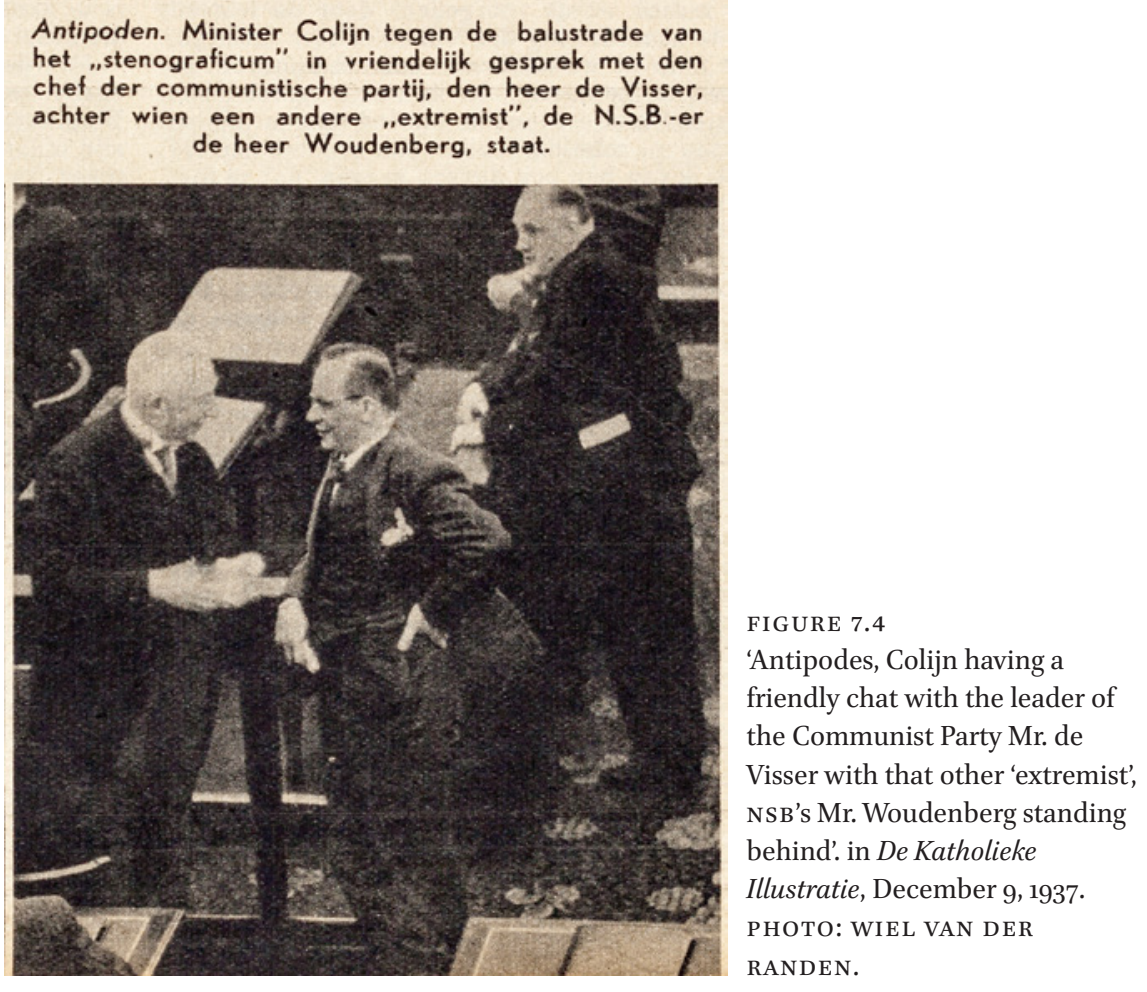

53-70,00o papers in the interwar period) provided mild critique on Colijn's political leadership. The caricature below appeared after "Prinsjesdag" 1935, the day that government expounds upon the policies for the coming year. Here we see how destructive the opposition can be when they really aim at an unsuspecting political leader. Colijn is portrayed as a weak leader, hiding from the hunters of the parliamentary opposition in his hare's lair. However, the artist aims his arrows more at the irresponsible leaders of the opposition. He deeply regrets that they are not at all constructive, but appear ready to shoot down government policies (see Figure 7.5).

The National Socialist newspaper Volk en Vaderland (circulation of 80,000) gave even more critique to Colijn's personal demeanour. The PM was portrayed as a weak leader. Volk en Vaderland did not just blame political parties but laid it squarely at Colijn's feet. For instance, the PM would be depicted as an easily influenced schoolmaster, and we see Mr. Colijn being addressed by his pupils while Anton Mussert, leader of the NSB, watches from the doorway. The pupils ask Colijn to stop Mussert entering the classroom because they are "scared" of him. The second cartoon has him doing just that, apparently being forced into 


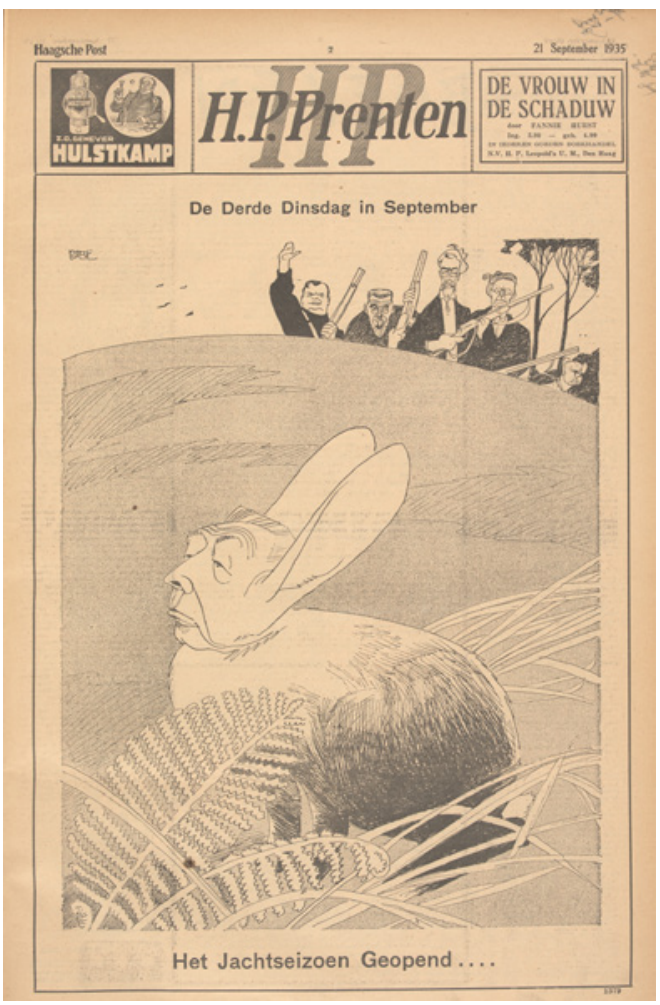

FIGURE 7.5

'Third Tuesday in September. Hunting season is opened...' in Haagsche Post, September 21, 1935. ARTIST UNKNOWN.

it by the pupils hanging on to his belt and pushing him towards Mussert (see Figure 7.6a). These cartoons refer to the new regulatory measure Colijn had enforced to combat political extremism. The NSB was not initially affected by the ban that had been decreed under civil servants in the summer, but parliamentary pressure made Colijn decide to extend the ban to the NSB in 1933, and members of this party were given the choice: revoke your membership or leave the civil service. A third cartoon show the same schoolmaster and his pupils doing a little jig in the classroom: "Right boys, the danger has passed! He's gone!" (see Figure 7.6b). In the background, we can see the large figure of Mussert at the classroom window, with a resolute expression: they're not done with him yet! This is to symbolise Mussert's position both above and outside this parliamentarian spectacle. In the eyes of the NSB, Mussert was the only leader capable of tough leadership, not Colijn; no way would Mussert succumb to pressure from others, as Colijn had certainly done.

National Socialists used cartoons to corroborate that the parliamentary system made it impossible to govern decisively. In 1936, in Volk en Vaderland, Maarten Meuldijk portrayed the ministers in Colijn's third cabinet as horned 


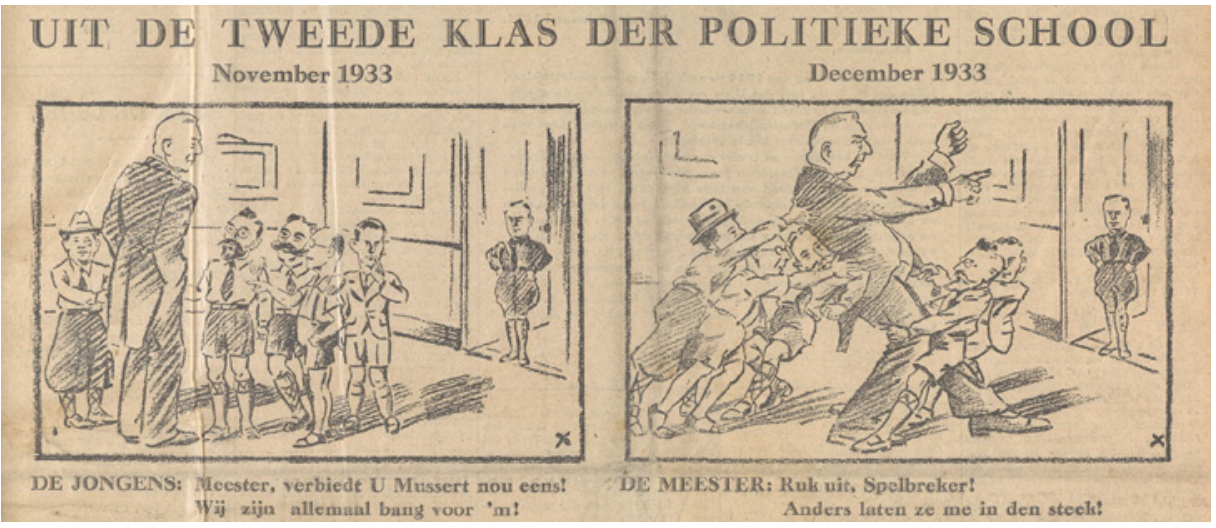

FIGURE 7.6a 'Primary 2 at politics school' November 1933. Boys: 'Sir, please ban Mussert. We are all scared of him!' December 1933. Schoolmaster: Get lost you spoilsport! Or they will all leave me! in Volk en Vaderland, January 6, 1934. ARTIST UNKNOWN.

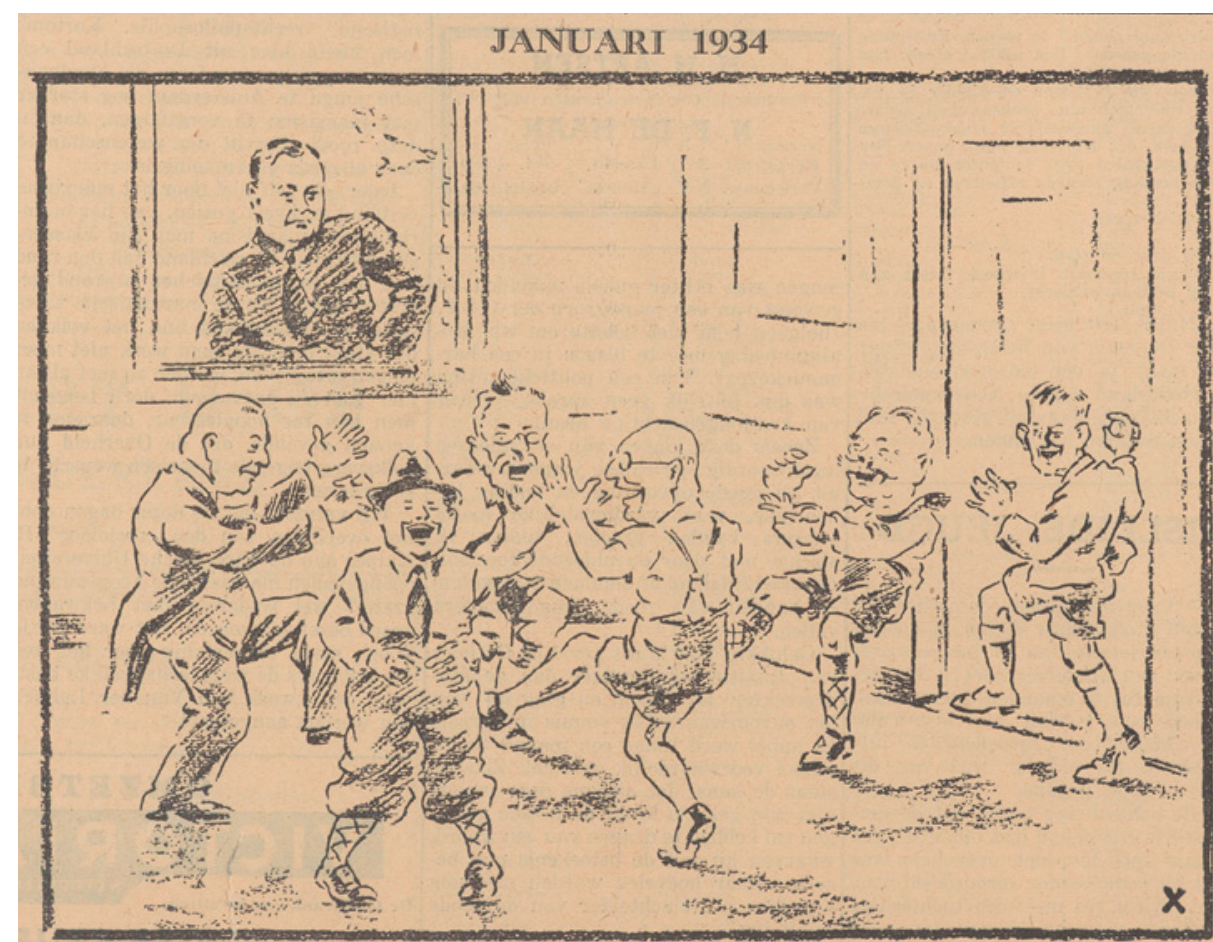

DE MEESTER EN DE JONGENS (in koor): „Jongens; het gevaar is geweken! Hij is weg!"

FIGURE 7.6b 'January 1934. Schoolmaster and teachers (together): 'Right boys, the danger has passed! He's gone!' in Volk en Vaderland, January 6, 1934. ARTIST UNKNOWN. 


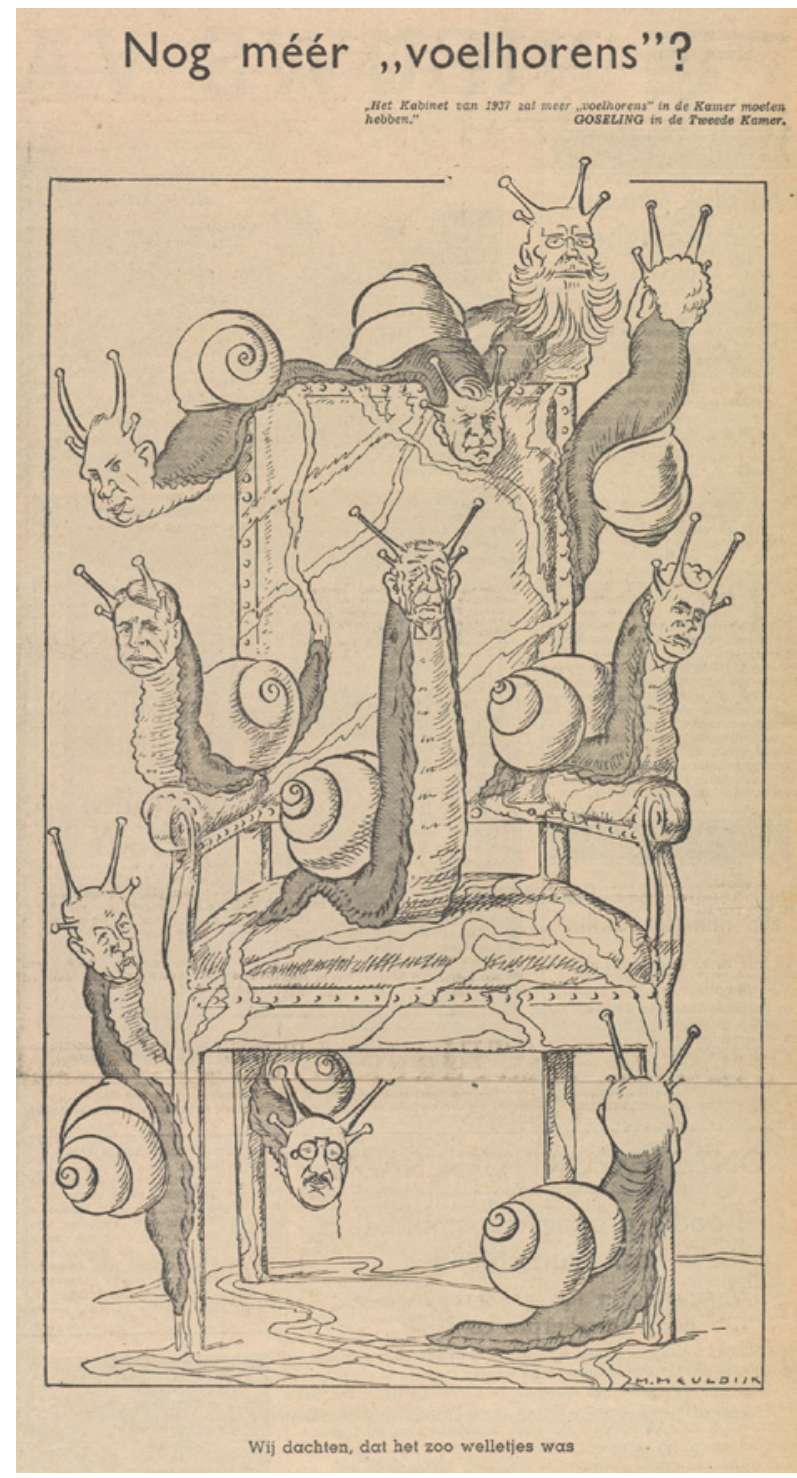

FIGURE 7.7

'Nog méér voelhorens?' in Volk en Vaderland, November 20, 1936. ARTIST: MAARTEN MEULDIJK.

slugs that left a trail of slime on their chairs in the Senate. A powerful image, suggesting that ministers are slow, indecisive individuals, too much attached to parliament and its plush velvety chairs to ever be decisive on anything. The sketch was accompanied by words attributed to the Catholic party chairman Carel Goseling who had earlier advocated that "the Cabinet [...] should have more 'feelers' in the House" (see Figure 7.7). 
This "proved" to the NSB, even more, that the parliamentary-democratic system could never produce a decisive government. Administrators listening too closely to parliament could not be expected to lead. This was most unsubtly portrayed in a series of cartoons in Volk en Vaderland. "Democracy" was represented as an abyss; or a dangerous disease; or a frozen, muddy canal full of holes in the ice; or a murky pond with a corpse floating in it; or a politician with a mill-stone tied around his neck. ${ }^{27}$ The message was clear: no good could be expected from democracy and its weak political leaders, so the democratic system should immediately be dispensed with.

\section{Colijn Portrayed as Disciplined Democrat}

The National Socialists were not the only Dutch with cravings for a "man of action." ${ }^{28}$ The call to be authoritative resounded equally in Catholic, Protestant, and liberal circles. These conservative parties represented the majority of voters. Endless debate in parliament was discredited and more confidence was displayed towards decisive leaders in general. These politicians should not waste their time in parliamentary chitchat, but should solve national problems. They should put an end to "The Great Depression" that had held the Netherlands in its sway since 1931, as well as to the alleged undermining of authority by extremists and insurgents. ${ }^{29}$

However, Catholic, Protestant, and liberal groups differed from the NSB on two main points. In the first place, conservatives believed that democracy was indeed capable of enforcing authority, and parliamentary democracy was in no way a hindrance to any form of decisive government (as opposed to what the National Socialists insisted was the case). Moreover, authority was an indispensable part of the democratic system. This then meant that any call for a strong leader must not be looked upon as a rejection of democracy. It would be more accurate to speak of a desire for a "more disciplined democracy." ${ }^{30}$ This term was launched by the lawyer Karl Loewenstein in the second half of the 1930s. He, too, had fled Nazi Germany, just as Salomon had done. In this conception of democracy, an inflexible leader was required - one that was not quickly disconcerted by any opposition. This leader must keep control of parliament and "the people." A true leader must be an "man of action" - resolute

27 "De twee honden en de doode ezel," Volk en Vaderland, 8 Jan. 1937; "Democratie is een gevaarlijke ziekte," Ibid., 15 Oct. 1937; “Goseling op glad ijs," Ibid., 23 Dec. 1938; “Monopoliebus," Ibid., 6 Jan. 1939.

28 Houwink ten Cate (1995) 218-19.

29 Gijsenbergh (2015) 122.

$30 \quad$ Loewenstein (1938) 774. 
and unshakable. The Catholics, Protestants, and liberals saw Colijn as the epitome of just such a leader. To them, that was actually the reason to support Colijn. It is characteristic of Colijn's stature as a statesman that many, even in the opposition, praised his leadership qualities in the 1930s. This was the second obvious difference to the NSB, who continually criticised Colijn's leadership. $^{31}$

Colijn liked to present himself as a decisive leader. He postulated that government, by its very nature, had an "inherent right" to lay down the law to its subjects, whatever the will of the people. In his view, sovereign power did not rest in the will of the people, nor in a strong parliament, but in the inherent right of government ministers exercising their given authority. He was aiming here not only at a strong cabinet, but on an influential monarch. Colijn, along with many citizens at that time, envisioned a disciplined democracy with a strong leadership as requisite for the continuance of parliament in times of crisis. He warned, during an election speech in 1933: "A purposeful government, that does not completely ignore popular influence, should find a majority in parliament, upon which it can rely."32 Colijn wished his cabinet to benefit from a powerful position, and therefore tapped into the widely felt need for authority.

Many magazines and their caricaturists reinforced Colijn's image as "man of action." He was portrayed as a strict, yet just, authoritative figure upon whom the Dutch people could rely. The compiler of Colijn in Caricature (1936) would for instance call this Prime Minister "Holland's Great Statesman." ${ }^{33}$ Even Salomon, generally in pursuit of the concept of thoughtful leadership, presented Colijn at times as a figure of authority. He did so, for instance, in his report on a visit of guests from the Dutch East Indies to the Netherlands in 1937, which portrayed the PM in his official robes of office. These symbols of power provided Colijn with the authority pursuant to a long tradition of state. It also helped that the famous "Grote Kerk" in The Hague was the background of the picture, rather giving Colijn a divine blessing (see Figure 7.8). ${ }^{34}$ Salomon hereby staged the PM's authority with this picture. He did so quite deliberately, as it turns out from an interview in the left/liberal periodical De Groene Amsterdammer. In 1937 he herein heaved a sigh, saying "conditions across the whole world would perhaps be improved if only leaders would actually lead." 35

\footnotetext{
$31 \quad$ Gijsenbergh (2017) 140.

32 Colijn (1933) 314-15; see also Langeveld (2004) 40, 246-47.

33 Bottema (1936) 3.

34 "Bezoek van 'Indische gasten," Het Leven, 16 Jan. 1937. See also the photos published at the occasion of the engagement of Princess Juliana: De Vries (1963) 150, 154-55.

Salomon (1937).
} 


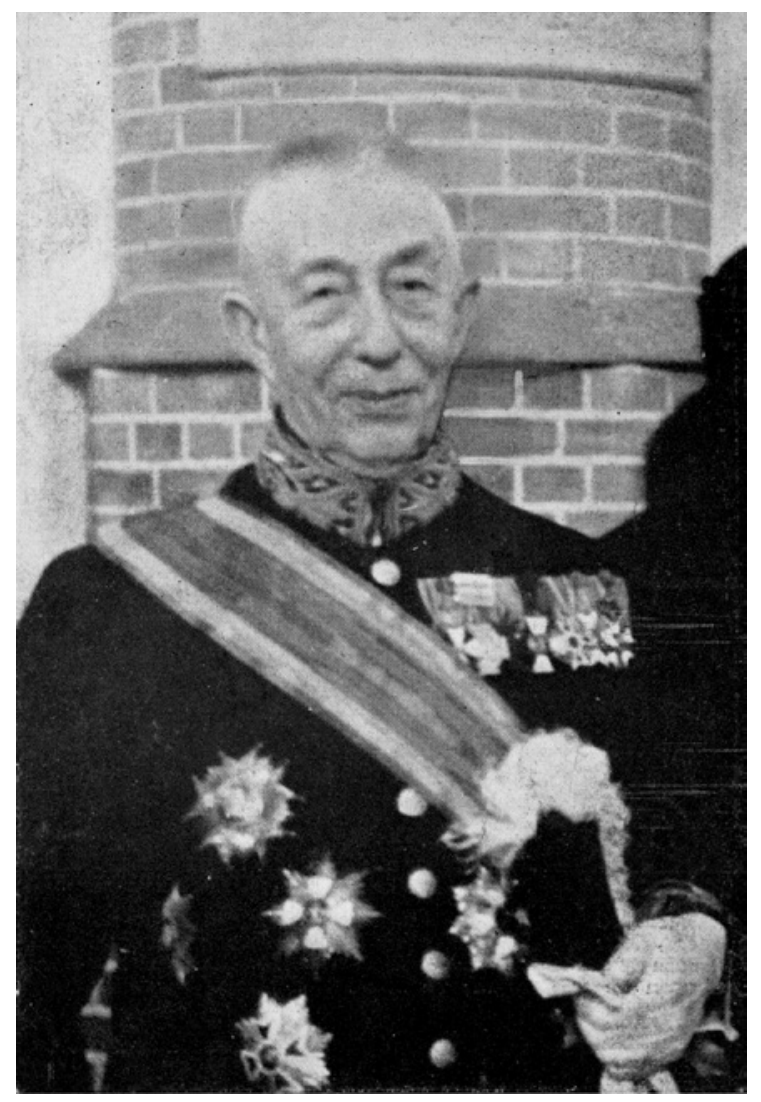

FIGURE 7.8

Traditional staging of a statesman in Het Leven, January 16,1937 .

PHOTO: ERICH SALOMON.

Salomon's call for a leader who knew what he was talking about seems to defy his concept of thoughtful leadership. However, Colijn's purposeful leadership seemed legitimate to Salomon and indeed necessary in times of crisis, as long as it remained within the framework of the parliamentary system. Salomon's work in Germany illustrates this apparent contradiction more clearly. Salomon had attempted to portray the Weimar Republic's Reichstag using various photographic methods plus visually aesthetic means in order to make it appear as a type of parliament full of deliberating gentlemen who were both accountable and at the same time close to the people. ${ }^{36}$ In his view, the Reichstag was not only the place of parliamentary debate, but also an arena for big performances by "statesmen." His intention was to portray the Reichstag as the representative centre of the Republic. His photographs of the bearing of various political chiefs, in their capacity as members of government, can all be

$36 \quad$ Biefang (2014) 33, 41, 88. 
seen as a visual argument for the opinion - or better yet, the hope - that not only an authoritative regime but also a parliamentary democracy, was capable of producing authoritative political leaders. In Salomon's opinion, thoughtfulness and thoroughness were fine bedfellows. The rise of the Nationalsozialistische Arbeiterpartei (NSDAP) in Germany shattered that dream, and yet Salomon was not discouraged.

The call for strong leadership is also clear in the captions to Salomon's photographs in Het Leven. This was one of the many periodicals that welcomed Colijn's authority. Unfortunately, without seeing the actual correspondence, it is not possible to find out how much influence Salomon actually had on said captions. Some indications on the back of the original photos in the archives could indicate that his suggestions were adhered to. ${ }^{37}$ And yet, it is likely that the editorial staff had the final say on any accompanying text, with which they were actually commenting on any pictures of Colijn. These captions were often concentrated on the parliamentary discussion as expounded upon in a previous paragraph, but often enough effectively emphasised Colijn's tight hold on the reins of leadership. A picture then emerges of how Colijn enjoyed his reputation and standing in parliament and how he really stood his ground against critical opponents within The House. The message implied that the PM deserved the respect of all Representatives as well as citizens, because he aimed to preserve national interests. Het Leven paid a great deal of attention to the parliamentary arena, but was a big advocate for strong leadership.

One good example is the text accompanying photos of the "parliamentary film" called "Colijn speaks, Colijn listens, Colijn directs" of February 1936 (see Figure 7.1). The title itself indicates that the PM is not only in debate with the Senate, but was entirely in charge. The tone of the caption tells us that Het Leven applauded this addition of the directorial element to democracy. The editorial staff glorified Colijn for his "huge intellect" that allowed him to defend government policy "majestically." They also emphasised that "[...] Colijn's raised index finger exhorts us to pay good attention." This "characteristic gesture made by our Prime Minister" does not go unnoticed because "The Parliament [listened] enthralled." When one MP deigned to criticise, "this opponent was summarily responded to." The caption for a close-up of the cabinet table (above, right) underlines here "just how far from being in agreement" the ministers listened to criticism. The editorial staff brings our attention to this, just in

37 Salomon himself glued the photos together, as a collage. That was meant as an instruction for the editorial staff. Furthermore, he wrote texts on the back of the photos, such as "Colijn thinks." Berlinische Gallerie, nr. 3 (1936) and nr. 18 (1939), Niederlande XII: Dr. Erich Salomon. 
case readers themselves had missed the obvious irritation clearly legible on the faces of cabinet members. ${ }^{38}$

Colijn was indubitably satisfied with this representation by Het Leven because he had personally complained, during the debate in the Senate, that the fragmented parliament cooperated insufficiently with the cabinet. ${ }^{39}$ Remarkably, the regional, Catholic newspaper Nieuwe Venloosche Courant, actually feared that the photo of the cabinet table in Het Leven could damage the State's reputation. This comment shows that this newspaper also felt that the PM should enforce respect. Unfortunately, there are no other comments in relation to this photo that could make it possible to work out how representative this Catholic newspaper's opinion was. What is clear, though, is that the Nieuwe Venloosche Courant felt that the evident staging of this photograph clashed with any dignity the government commanded:

Mr. Oud's listless attitude gives us to assume that he is listening to a speech on fundamental, positive Christianity. Wizard Colijn holds his hands to his temples as shells, so imitating a bat; or perhaps a Maori. [...] We surely possess an imposing collection of respectable portraits of our ancestors. [...] But when history completes the chapter on the turbulent era of Colijn's Crisis Cabinet, just one such photo from the archives need be recovered and our descendants will only be able to assume that we all descend from a ridiculous bunch of idiots. What happened to honouring history? ${ }^{40}$

Het Leven's admiration and respect for the PM is further evident in the captions to Salomon's photographs of Colijn's situation at home. Public space was apparently no longer sufficient for a number of journalists to get on top of this politician's personality. They tried infiltrating the personal life of politicians. ${ }^{41}$ Salomon hooked up to these new mores and photographed the Colijn family in a private capacity. Editorial staff at Het Leven used a photo of Colijn's dining room to indicate the importance of order and authority both at home and in the political arena: "Tranquillity and sobriety define this house, where Mrs. Colijn rules with an iron fist, just as her husband does in meeting rooms across the country." The captions on several photos of Colijn in his office spread the same message: "Under his leadership, the people of The Netherlands have

\footnotetext{
$38 \quad$ Het Leven, 22 Feb. 1936.

39 HEK 1935-1936, 272.

$40 \quad$ Cited in Bool (1979) 134.

41 Broersma, "Mediating Parliament," 180.
} 


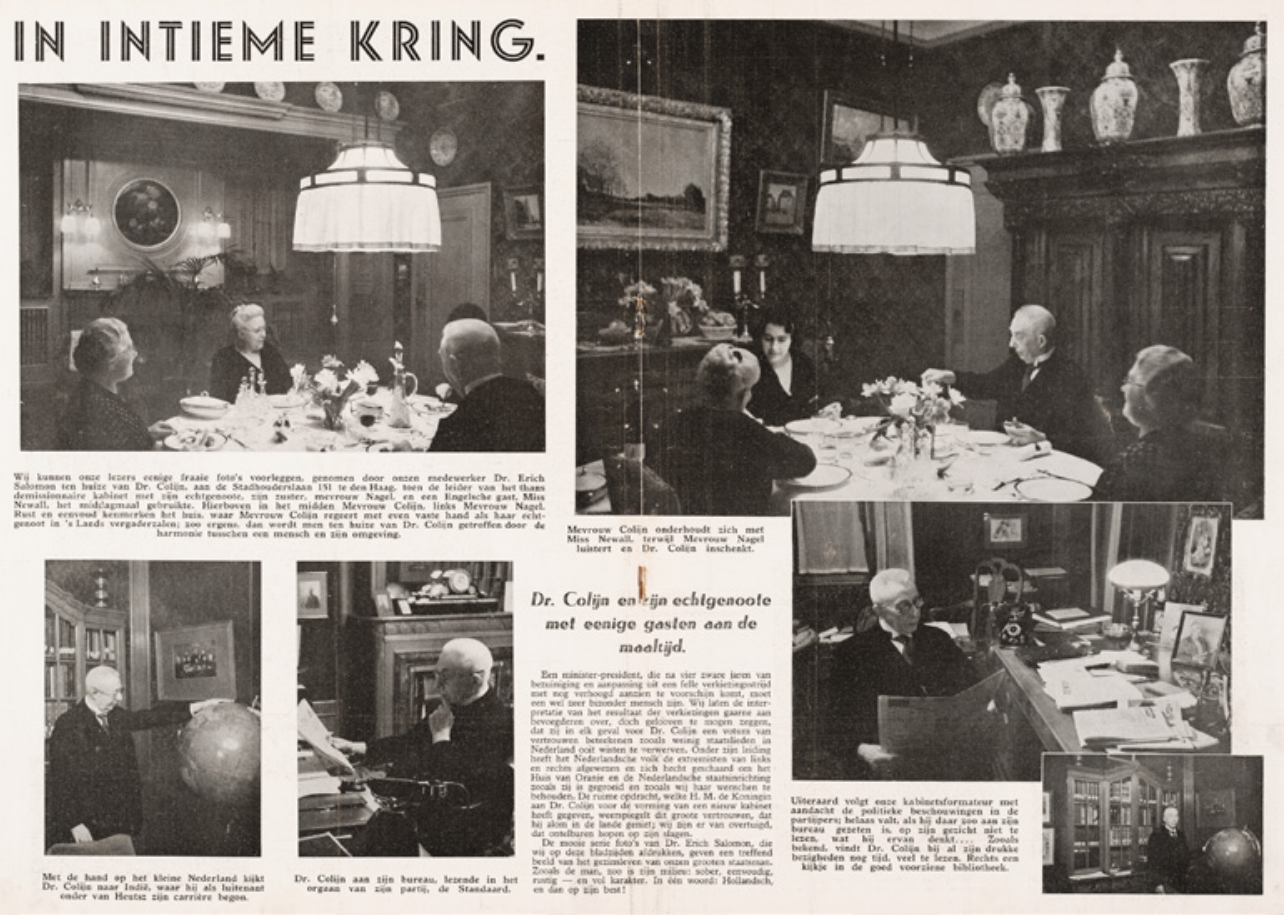

FIGURE 7.9 Private and public within politics in Het Leven, June 5, 1937.

PHOTOS: ERICH SALOMON.

rejected the extremists on both right and left, and are ranged closely around the House of Orange and the Dutch form of government [...]." Het Leven was indeed totally unsurprised that Colijn, during parliamentary elections for 1937, was once more awarded a huge "vote of confidence" from the electorate (see Figure 7.9$){ }^{42}$

There were other papers besides Het Leven that showed appreciation for Colijn's strict style of leadership. De Haagsche Post and the popular newspaper De Telegraph led the way here. These papers praised his energy, not just in the articles in the paper but also in their political cartoons of Colijn. Their caricaturists also used multiple metaphors for "school" to depict his style of political leadership. This metaphor was however much more positively portrayed than it was in Volk en Vaderland. The politician - usually a minister - was now seen as a teacher with authority, leading the country and its parliament. For instance, Eppo Doeve of De Haagsche Post depicted Colijn as a stern looking schoolmaster, with all the MPs depicted as school children. Colijn towers above

42 "In intieme kring," Het Leven, 5 June 1937. 


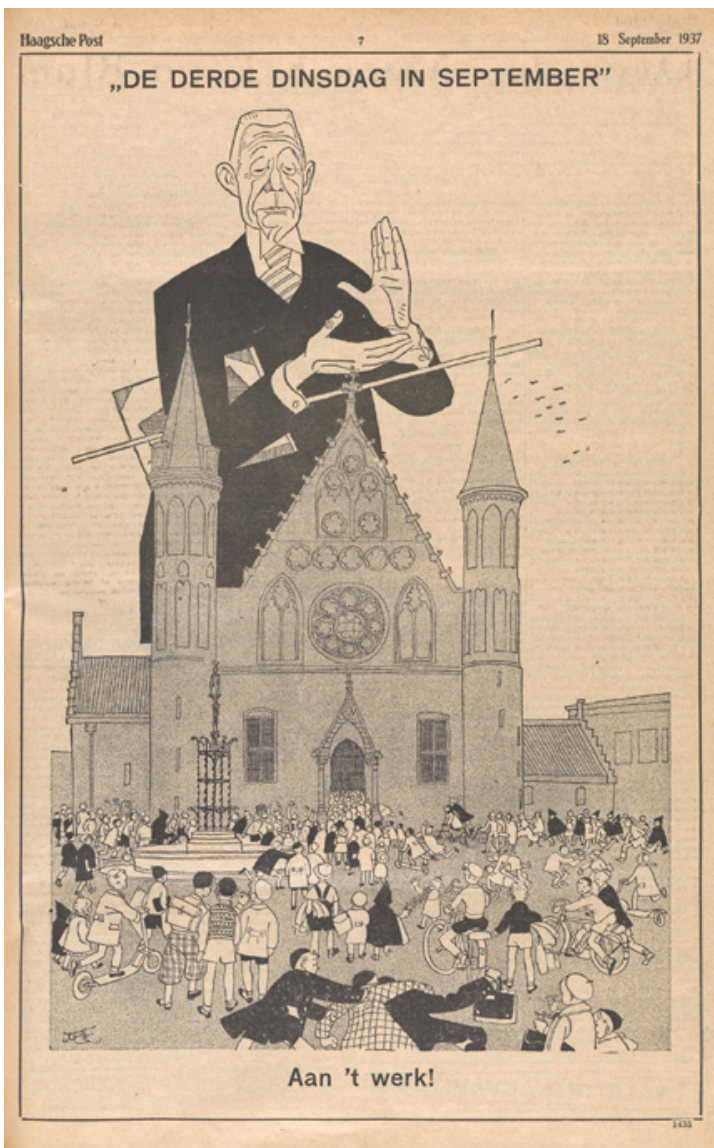

FIGURE 7.10

'The third Tuesday in September: 'Get to work!'. PM/School Master H. Colijn, calls the playing MPs/ school children to attention, on the opening day of the parliamentary year in Haagsche Post, September 18, 1937. ARTIST: EPPO DOEVE.

the playing children on "het Binnenhof" and calls them to attention. This cartoon appeared around the third Tuesday in September, the very day of the opening of parliament in "de Ridderzaal" in The Hague. This depicted Colijn's stature: he was the dominant figure in Dutch parliamentary politics and all members of parliament were subject to his authority (see Figure 7.10).

Most political caricaturists harked back to the ancient metaphor of the nation's flagship, captained most capably by the statesman. According to historian Te Velde, this had to do with the political climate of that decade which frequently put the government under a lot of pressure. ${ }^{43}$ It was a powerful image that fitted very well to Dutch history with all its famous naval heroes. The power of the image was also evident in its versatility: the wild seas and dangerous rocks and cliffs representing threats the country had to endure. The 


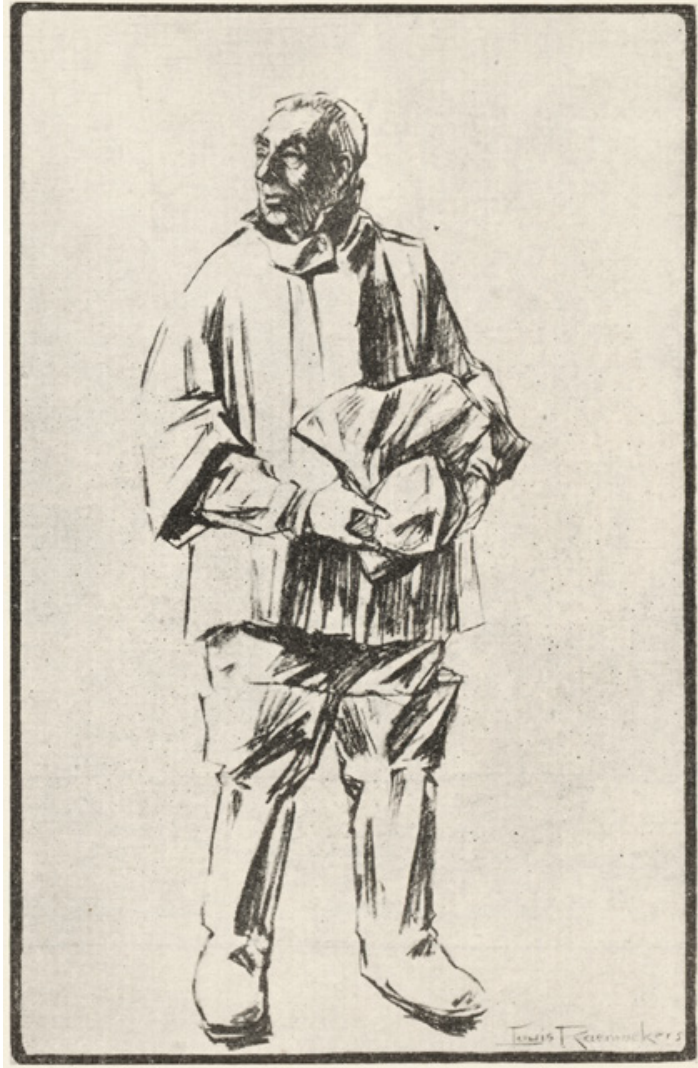

Louis Racmaekers.
FIGURE 7.11

Captain of the Ship of State in De Telegraaf, September 24, 1933. ARTIST: LOUIS RAEMAEKERS.

rudder and sails of this great ship also played their role: symbolising "good" fundamental concepts that would help steer those ocean highways. It required an able man at the helm to ensure that the great ship was never sunk. Following "Prinsjesdag" on 19 September 1933, caricaturist Louis Raemakers made use of this image. He depicted PM Colijn as a composed captain on the "ship of state," well prepared for the storms to come. The image fitted the call for a powerful statesman capable of guiding The Netherlands through the most turbulent of storms (see Figure 7.11).

Leen Jordaan also depicted Colijn in De Groene Amsterdammer as helmsman of a great ship in the middle of a fierce storm. Holding tight to the ship's wheel ("parliamentary democracy") with, in the background, two ships of state, run aground beneath the cliffs: France and Austria had been "sunk" through "politics" and a "cabinet crisis." "Politics" had obvious negative connotations in this cartoon. Both countries had indications of huge instability: 


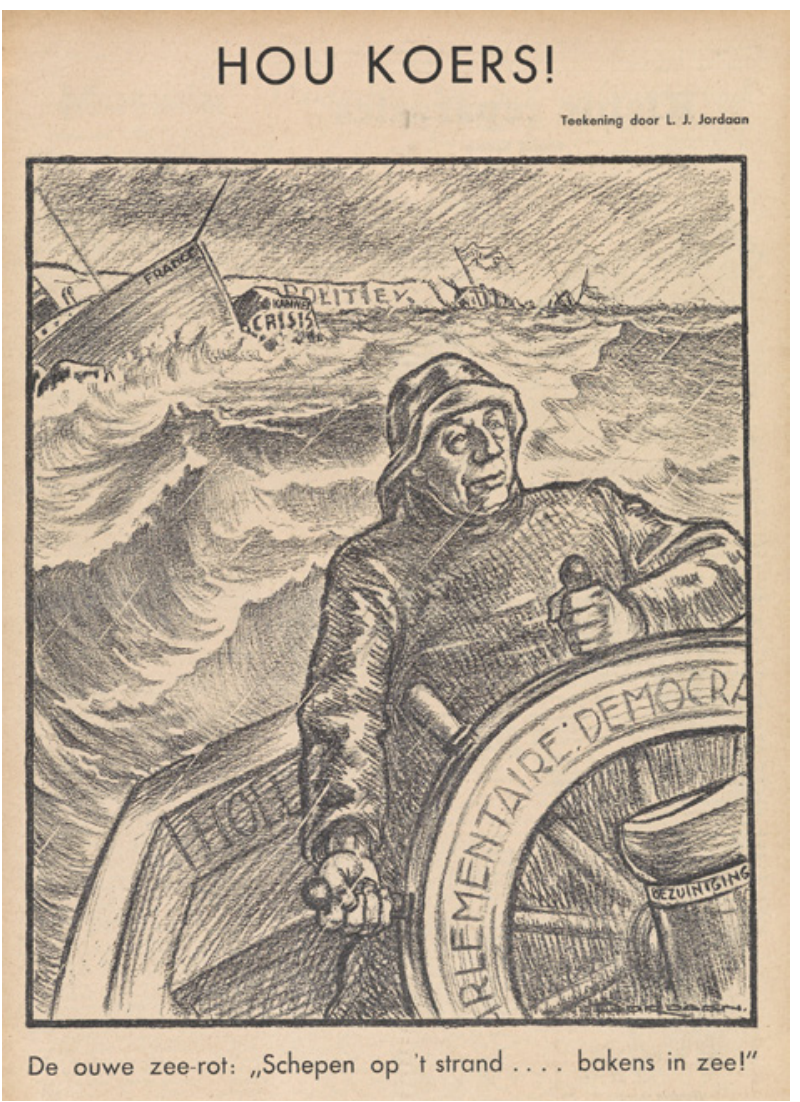

FIGURE 7.12

'Hold that course!' Here we see PM Colijn depicted as Captain of HMs of State 'Holland', holding fast to the wheel of 'parliamentary democracy' and steering the ship well away from the cliffs of 'politics' and 'cabinet crisis', upon which France and Austria have already floundered in De Groene Amsterdammer, October 28, 1933. ARTIST: LEO JORDAAN.

France was constantly changing from one government to the other, while violent attacks by members of the National Socialist party in Austria caused unrest. This shows that even a progressive paper had faith that Colijn could save the country from ruin (see Figure 7.12).

At the same time, the summons "Hold that course!" above the cartoon can be read as a warning to Colijn. The Dutch HMs of State could only defy all storms if Captain Colijn kept to the course determined by parliamentary democracy. ${ }^{44}$ If the prime minister would systematically ignore the parliament, or even shut down his critics, parliamentary democracy was under threat of extinction from within. This cartoon evokes not only the classical image of Colijn as capable helmsman, but made evident the fear that the PM's continued insistence on action could be at the expense of the will of the people. ${ }^{45}$

44 L.J. Jordaan, "Hou koers," De Groene Amsterdammer, 28 Oct. 1933.

45 Gijsenbergh (2015) 254-56. 
Jordaan's cartoon exposes just how far the "navigation" metaphor could be taken. Progressive supporters of parliamentary democracy were willing to accept strong pilots, on condition that they worked within the framework of democratic representation. Jordaan made this plain more than once, exposing his own less than complete support of the idea of a disciplined democracy. ${ }^{46}$

The Social Democrats were clearer in their aversion to a disciplined democracy and strong leadership. Their complaint was that Colijn - who demanded to be allowed to govern, unhindered - gagged any opposition. This concerned them greatly because the SDAP was invariably in opposition until 1939. Social Democratic cartoonists protested that strong leadership was contradictory to true democracy because a "man of action" refused to listen to critique. ${ }^{47}$

Albert Hahn Jr. criticised Colijn's lack of respect for anyone else's point of view, by portraying him as a man putting up his collar and dashing through a storm of papers full of criticism for his policies as they rain down upon him. The caption shows just how unimpressed this Social Democratic cartoonist was by Colijn's defence that "White Papers" were demagogic: "despicable demagogy $[. .$.$] but where is it actually relevant?" This caption addressed the gov-$ ernment's reaction to criticisms made by (among others) Social Democratic MPs on the government's financial-economic policy. The government had informed parliament that "it could only be a remarkable lack of perception, or indeed a despicable demagogy" that could incite anyone to voice this critique, because the government had after all no say in international financial-economic developments. ${ }^{48}$ De Notekraker explained this differently: the use of the harsh term "demagogy" showed that there were apparently no relevant arguments to be made against the critique given by the SDAP. The cartoon literally depicted Colijn running away from his responsibilities, instead of subjecting himself to democratic control and answering the questions of the parliamentary opposition about his cabinet policies. With this sketch, Hahn showed a different view than Salomon's photos and their corresponding captions in Het Leven, which showed understanding towards cabinet ministers' frustrations at having to endure critique from the parliament. ${ }^{49}$

Social Democrat George Van Raemdonck went further than Hahn - he threw Colijn in the same pile as other aspirant "strong men" like the leader of the NSB, Mussert, and the foremen of fascist splinter movements. Van Raemdonck accused Colijn of actually awakening fascism. In his cartoon, he has

\footnotetext{
46 Jordaan, "Kamerontbinding" and "Begrootingsdebatten", De Groene Amsterdammer, 18 Feb. 1933 and 10 Nov. 1934.

47 Gijsenbergh (2013) 164.

$48 \quad H T K, 1934-1935$, no. 362, sub no. 3.

49 Het Leven, 22 Feb. 1936; Bottema (1936) 108-11.
} 
Colijn nursing an emaciated baby at the breast, wrapped in a swastika. In Van Raemdonck's view, Colijn was no better than the National Socialists and fascists, who also both rushed to provide milk. Van Raemdonck placed PM Colijn in line with persons and groups that the artist himself called extremist or reactionary. On this list he counted NsB leader Mussert, W.M. Westermann (chief of the Verbond voor Nationaal Herstel (vNH ), B.Ch. de Savornin Lohman (prominent protestant member of the Senate and a great admirer of Colijn), A.R. Zimmerman (the authoritarian Mayor of Rotterdam), anti-Semites, Catholic fascists, and the Lutheran Church.

This caricature shows how political commentators in the 1930s could not avoid "the strong man." All sorts of politicians, from the National Socialist Mussert through to the disciplined democrat Colijn, presented themselves as the decisive leader. This self-representation was reinforced through photographs and political cartoons. The call for decisive leadership was generally repeated, but in progressive circles, protests could be heard against this form of political leadership.

\section{Conclusion: Iconography on Leadership in Dutch Democracy}

During the interwar period, the image of Dutch political leaders partly depended on cultural imagery. PM Colijn and other persons in charge could win the confidence of the voting public if they were portrayed in a positive way, but were at risk of losing that same vote of confidence if they were shown in an unfavourable light. Leadership representation mostly appeared in printed newspapers and magazines, given that this media had the largest coverage. Parliamentarian photographers, caricaturists, and editing staff of illustrated journals also influenced the reputation of politics. Although the number of illustrated journals was limited, they brought the political area literally "in the picture." Of course, this did not result in a realistic depiction (mimetic representation) of these "men of state." On the contrary, the illustrated journals tended to place the politicians in a particular light (aesthetic representation). Their compositions, use of metaphors, and their captions rather "framed" the political leaders' demeanours. They attempted to legitimise as well as delegitimise certain types of leadership. This indicates that visual sources support us in analysing the intangible process of representation. Analysis of photographs and political cartoons has shown which ideal images of leadership were presented to the citizens of the Netherlands.

The first idealised image of politics was deliberative leadership, in which cabinet members held courteous, constructive discussion with members of 
parliament. MPs played an important part in this repertoire of representation because they controlled the government. There were indeed proponents to be found for this type of independent parliament. It was especially the Social Democratic caricaturists who sketched parliament of the 1930s as the central arena of Dutch politics, where the masters, those in charge, should be thoroughly investigated. Previous scholars have too often emphasised that Social Democrats were reluctant to exchange their old revolutionary strategies for parliamentarian tactics. Most Social Democrats in the 1930s embraced a strong parliament, especially in the hope of being heard, despite their position in opposition.

Caricatures in National Socialist and conservative journals instead advocated authoritative leadership. In their view, the "man of action" should pay as little heed as possible to critical members of parliament. The NSB went far in this and postulated that strong leadership was only possible after the abolishment of parliamentary democracy. Conservative cartoonists working for $D e$ Haagsche Post and De Telegraph were somewhat milder. They deemed it possible to combine democracy with strong leadership. Colijn fitted the picture there, as far as they saw, by leading the country as a stern schoolmaster, or a capable skipper. They appreciated the fact that Colijn appeared to hold the reins in the Binnenhof.

These two ideal images of political leadership were often enough combined - for instance in the images in De Groene Amsterdammer, in the photos by Erich Salomon, and in the relevant captions in Het Leven. It is understandable that Salomon craved debate and spirit, given his personal experience of the rise of the NSDAP in his homeland. After seeing the demise of the Weimar Republic, Salomon put the spotlight on the auspicious side of the Dutch parliament that reminded him of the nineteenth century parliament filled with dignified and respectably deliberating gentlemen. At the same time, he realised that his ideal was unrealistic now that the economic crisis had led to complaints about a parliamentary "chat club." Salomon's solution was to have a strong leader who solved problems within the framework of the parliamentarian system. This particular feature of Colijn was just what Salomon appreciated, so he was happy to promote Colijn's image of "man of action." The image took off in Holland because it hooked up nicely with both the Dutch tradition of deliberation from the nineteenth century and the desire for momentum in the 1930 s.

The various ways Colijn was represented demonstrate the huge diversity in Dutch interpretations of democratic leadership. The PM's style of leadership was both criticised and praised, based on manifold arguments. How the PM was to lead was subject to debate but despite all the differences of opinion on 
the matter, an important shift became visible in the shape of representative politics throughout the 1930s. A return to the nineteenth century, with parliament populated by eminent gentlemen, was ruled out. Deliberating parliamentarians did not exactly disappear from the stage, but they did now have to tolerate a strong Prime Minister among them. Most Dutch citizens welcomed such developments. It was not seen to be as a hollowing-out of the democratic system, but more as an improvement to it. Exactly how the leader should comport himself remained controversial, but it was undisputed that he now, himself, represented the nation. The photographs and caricatures here researched enhanced his charisma and the acceptance of his power.

\section{Bibliography}

Aerts, R., "Besloten openbaarheid. De representatie van het Nederlandse Parlement," in A. Biefang and M. Leenders (eds.), Erich Salomon \& het ideale parlement. Fotograaf in Berlijn en Den Haag, 1928-194o (Amsterdam, 2014), 137-160.

Aerts, R., Het aanzien van de politiek. Geschiedenis van een functionele fictie (Amsterdam, 2009).

Ankersmit, F.R., "Politieke representatie. Betoog over de esthetische staat," in $B M G N-$ Low Countries Historical Review, 102, no. 3 (1987), 358-379.

Berg-Schlosser, D., and J. Mitchell (eds.), Conditions of democracy in Europe, 1919-1939 (Basingstoke, 2000).

Biefang, A., "Het einde van deliberatie. De foto's van Erich Salomon van de Rijksdag 1928-1931," in A. Biefang and M. Leenders (eds.), Erich Salomon \& het ideale parlement. Fotograaf in Berlijn en Den Haag, 1928-1940 (Amsterdam, 2014), 21-88.

Bool, F., "Foto '37," in F. Bool and K. Broos (eds.), Fotografie in Nederland 1920-1940 (The Hague, 1979), 127-143.

Bottema, T., E. Doeve and A. Hahn (eds.), Colijn in de caricatuur. Honderd uitgezochte caricaturen met een voorwoord van Dr. Colijn zelf (Baarn, 1936).

Beunders, H., and M. Kleppe, "Een plaatje bij een praatje of bron van onderzoek? Fotografie verwerft geleidelijk een plek in de historische wetenschap," in Groniek 187 (2010), 121-139.

Brandt, B., "Writing Political History after the 'Iconic Turn,"” in W. Steinmetz, I. GilcherHoltey, and H-G. Haupt (eds.), Writing Political History Today, (Frankfurt am Main, 2013), 351-357.

Burke, P., Eyewitnessing. The Uses of Images as Historical Evidence (London, 2001).

Colijn, H., Wankelen noch weifelen. Rede ter opening van de deputaten-vergadering, gehouden te Utrecht op donderdag 9 maart 1933 (Amsterdam, 1933). 
Föllmer, M., "Führung und Demokratie in Europa," in T.B. Müller and A. Tooze (eds.), Normalität und Fragilität. Demokratie nach dem Ersten Weltkrieg (Hamburg, 2015), 177-197.

Gerard, E., "Een schadelijke instelling: kritiek op het parlement in België in het interbellum," in BMGN - Low Countries Historical Review 120, no. 3 (2005), 497-512.

Gijsenbergh, J., Democratie en gezag. Extremismebestrijding in Nederland, 1917-1940 (Enschede, 2017).

Gijsenbergh, J., "Contrasting Complaints about Parliamentarism in Western Europe (1918-1939)," in K. Palonen and J.M. Rosales (eds.), Parliamentarism and Democratic Theory. Historical and contemporary Perspectives (Berlin, 2015), 117-139.

Gijsenbergh, J., and H. Kaal, "Kritiek op de parlementaire democratie in Nederlandse spotprenten," in A. Biefang and M. Leenders (eds.), Erich Salomon \& het ideale parlement. Fotograaf in Berlijn en Den Haag, 1928-1940 (Amsterdam, 2014), 201-220.

Gijsenbergh,J., "The semantics of 'democracy' in social democratic parties. Netherlands, Germany and Sweden, 1917-1939," in Archiv für Sozialgeschichte 53 (2013), 147-173.

Houwink ten Cate, J.H., De mannen van de daad en Duitsland, 1919-1939. Het Hollandse zakenleven en de vooroorlogse buitenlandpolitiek (The Hague, 1995).

Kennedy, J.C., "De democratie als bestuurskundig probleem: Vernieuwingsstreven in de Nederlandse politiek sinds 1918," in Jaarboek Parlementaire Geschiedenis (2004), 12-23.

Langeveld, H., Schipper naast God. Hendrikus Colijn, 1869-1944 (Amersfoort, 2004).

Langeveld, H., "De verzuiling doorbroken. Hendrikus Colijn en de liberale en ongebonden pers," in J. Bardoel and H. Wijfes (eds.), Journalistieke cultuur in Nederland (Amsterdam, 2002), 37-49.

Leenders, M., "Op zoek naar het ideale parlement - Erich Salomon in Den Haag 19361940," in A. Biefang and M. Leenders (eds.), Erich Salomon \& het ideale parlement. Fotograaf in Berlijn en Den Haag, 1928-1940 (Amsterdam, 2014), 89-122.

Loewenstein, K., "Legislative Control of Political Extremism in European Democracies. Part II," in Columbia Law Review 38, no. 5 (1938), 725-774.

Loots, J., Voor het volk, van het volk. Van districtenstelsel naar evenredige vertegenwoordiging (Amsterdam, 2004).

Mulder, H., Een groote laars, een plompe voet. Nederland en de Nazis in spotprent en karikatuur, 1933-1945 (Amsterdam, 1985).

Mulder, H., "De politieke spotprent tussen de beide wereldoorlogen," in C. Blotkamp and M. Boor (eds.), Kunst en Kunstbedrijf. Nederland 1914-1950 (Haarlem, 1978), 168-208.

Rose, G., Visual Methodologies. An Introduction to the Interpretation of Visual Materials (London, 2001).

Salomon, E., "Het onbescheiden oog," in De Groene Amsterdammer, 19 June 1937. 
Velde, H. te, Stijlen van leiderschap. Persoon en politiek van Thorbecke tot Den Uyl (Amsterdam, 2002).

Velde, H. te, "De spiegel van de negentiende eeuw. Partij, representatie en geschiedenis," in Jaarboek Documentatiecentrum Nederlandse Politieke Partijen (2001), 19-40.

Velde, H. te, "Van Thorbecke tot Den Uyl. Distantie en nabijheid in de Nederlandse politieke traditie," in D. Pels and H. te Velde (eds.), Politieke Stijl. Over presentatie en optreden in de politiek (Amsterdam, 2000), 152-175.

Vries, H. de, and P. Hunter-Salomon (eds.), Erich Salomon. Porträt einer Epoche (Frankfurt am Main, 1963).

Walter, A.S., and J.J.M. van Holsteyn, "Pim in prenten. De weergave van Pim Fortuyn in politieke tekeningen," Jaarboek Documentatiecentrum Nederlandse politieke partijen 2005 (2006), 176-205.

Weringh, K. van, De Houten Pomp: AR Caricaturistisch weekblad, 1922-1930 (Amsterdam, 1977).

Weringh, K. van, Getekende wereld, de kijk van F. Behrendt en Opland op het wereldgebeuren, 1961-1975 (Amsterdam, 1976).

Weringh, K. van, Albert Hahn: tekenen om te ontmaskeren. Biografie van de bekendste Nederlandse tekenaar (Amsterdam, 1975). 